\title{
ÁL-FÂHIM
}

\section{Jurnal Manajemen Pendidikan Islam}

Manajemen Strategi Pemasaran Pendidikan

Di SDIT Alam Nurul Islam Sleman

Jamaludin

Menakar Kebijakan Pendidikan Nasional Dan Pendidikan Islam Di Indonesia Era Reformasi (Presiden Habibie Sampai Presiden Jokowi Jilid I) Permana Octofrezi

Peran Kepala Sekolah Dalam Implementasi Manajemen Mutu

Peserta Didik (Smk Darul Maghfiroh Di Sinar Rejeki, Kecamatan Jati Agung, Kabupaten Lampung Selatan) Andrianto

Konsep Ulul Albab Dalam Manajemen Kepemimpinan Pendidikan Islam Nimas Wegig Kurniana

Analisis Kritis Kepemimpinan Pendidikan Islam Berdasarkan Syarat Dan Ciri-Ciri Kepemimpinan Yang Ideal Siti Qurrotul A'yuni, Radia Hijrawan

Menjadi Pemimpin Yang Efektif Dan Berpengaruh

Di Madrasah Munganatul Khoeriyah

Upaya Sekolah Dalam Meningkatkan Prestasi Non Akademik Siswa Melalui Manajemen Sarana Prasarana Di SMP Muhammadiyah Boarding School Pleret Safinatun Munawaroh, Rz. Ricky Satria Wiranata

Diterbitkan Oleh:

Prodi Manajemen Pendidikan Islam STAIT Yogyakarta 


\section{$\frac{\text { ÁL-FÂHIM }}{\text { Jurnal Manajemen Pendidikan stam }}$}




\section{ÁL-FÂHIM \\ Jurnal Manajemen Pendidikan Islam}

$\begin{array}{ll}\text { Penangung Jawab } & \text { : Danang Dwi Prasetyo } \\ \text { Ketua Redaksi } & \text { : Rz. Ricky Satria Wiranata } \\ \text { Editor } & \text { : Denas Hasman Nugraha } \\ \text { Reviewer } & \text { : Syarif Hidayat } \\ & \text { Suprih Hidayat } \\ \text { Tata Usaha } & \text { Sulis Ariawan } \\ & \text { Nita Kumalasari } \\ \text { Penerbit } & \text { Sekolah Tinggi Agama Islam Terpadu } \\ & \text { Yogyakarta } \\ \text { Alamat Redaksi } & \text { : Jl. Mendung warih No. 125 Giwangan, } \\ & \text { Umbulharjo, Yogyakarta } \\ & \text { Telp. (0274) 410350, 4281163 } \\ & : \text { redaksialfahim@gmail.com } \\ \text { Email } & \text { : jurnal.staitbiasjogja.ac.id } \\ \text { Website } & \end{array}$

\section{Deskripsi:}

ÁL-FÂHIM adalah jurnal Manajemen Pendidikan Islam yang diterbitkan secara berkala selama enam bulan sekali oleh Prodi Manajemen Pendidikan Islam Sekolah Tinggi Agama Islam Terpadu Yogyakarta berdasarkan Keputusan Ketua STAIT Jogja Nomor 001/A.KEP/STAITJOGJA/II/2019 tanggal 18 Februari 2019. Jurnal ÁL-FÂHIM adalah sarana kaum intelektual sebagai media informasi dan penyebarluasan hasil studi penelitian dan artikel ilmiah dibidang Manajemen Pendidikan Islam.

Jurnal ÁL-FÂHIM mengundang para Dosen, Pendidik dan praktisi Pendidikan Islam untuk menyumbangkan karya ilmiahnya di bidang Manajemen Pendidikan Islam. Naskah yang dikirim akan diseleksi dan dipublikasikan sesuai aturan dan ketentuan yang berlaku. Karya Ilmiah yang dimuat di Jurnal ÁLFÂHIM tidak selamanya mencerminkan pendapat redaksi. 
DAFTAR ISI

Vol. 02 No. 02 September 2020

Halaman Judul .................................................................................. $\mathrm{i}$

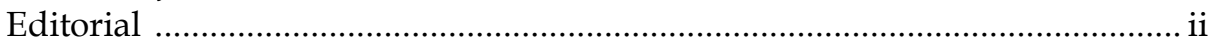

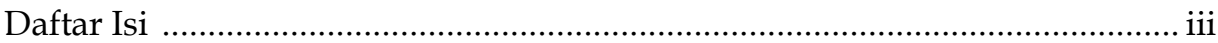

Manajemen Strategi Pemasaran Pendidikan Di SDIT Alam Nurul Islam Sleman

Jamaludin

Menakar Kebijakan Pendidikan Nasional Dan Pendidikan Islam Di

Indonesia Era Reformasi (Presiden Habibie Sampai Presiden Jokowi Jilid I)

Permana Octofrezi

Peran Kepala Sekolah Dalam Implementasi Manajemen Mutu Peserta Didik (SMK Darul Maghfiroh Di Sinar Rejeki, Kecamatan Jati Agung, Kabupaten Lampung Selatan)

Andrianto

Konsep Ulul Albab Dalam Manajemen Kepemimpinan Pendidikan Islam

Nimas Wegig Kurniana

Analisis Kritis Kepemimpinan Pendidikan Islam Berdasarkan Syarat Dan Ciri-Ciri Kepemimpinan Yang Ideal

Siti Qurrotul A'yuni, Radia Hijrawan ........................................................................ 68

Menjadi Pemimpin Yang Efektif dan Berpengaruh di Madrasah

Munganatul Khoeriyah

Upaya Sekolah Dalam Meningkatkan Prestasi Non Akademik Siswa Melalui Manajemen Sarana Prasarana Di SMP Muhammadiyah Boarding School Pleret

Safinatun Munawaroh, Rz. Ricky Satria Wiranata 


\title{
Menjadi Pemimpin Yang Efektif Dan Berpengaruh Di Madrasah \\ Munganatul Khoeriyah \\ UIN Sunan Kalijaga Yogyakarta \\ khoeriyahmunganatul@gmail.com
}

\begin{abstract}
Abstrak: The study to aim provides an overview of being effective and influential leader. This type of research is library research. This reaserch using books, article leadership looking for scientific facts, then analyzed by analisis description method. This research result reveal that instrumen efective and influential leader is impermanent. Leaedership style is determine influnce that he leads. Build the trust of school residents and the community through of leadership style is the key open the way succsess. Strong leader and management are needed for the succsess of the institution. Ulil albab is nickname for profiles of succsesfull leadership in madrasah.
\end{abstract}

Keywords: Leadership, Effective and Influential, Madrasah.

\section{Pendahuluan}

Kepemimpinan memang merupakan suatu topik bahasan yang klasik, sudah sangat tua usianya namun tetap sangat menarik untuk dikupas karena sangat menentukan berlangsungnya suatu organisasi. Kepemimpinan esensinya adalah pertanggungjawaban. Masalah kepemimpinan masih tetap menarik untuk diungkap karena tiada habisnya untuk dibahas di sepanjang peradaban umat manusia. Terlebih pada saat sekarang ini, persoalan menentukan pemimpin yang baik (good leader) sangat sulit. Salah satu permasalahan pemimpin di negeri ini banyaknya pemimpin yang tidak jujur dan bersih. Hal ini ditandai dengan banyaknya pemimpin yang korupsi. ${ }^{128}$ Pemerintah pusat mendududuki peringkat pertama dengan jumlah 359 kasus korupsi dalam rentang tahun 20042019.129

Kepala madrasah sebagai pemimpin lembaga pendidikan, terutama pendidikan Islam dalam menyelenggarakan tugas dan fungsinya sebagai pemimpin dan pengelola madrasah harus memiliki visi dan misi serta strategi manajemen pendidikan secara utuh dan berorientasi kepada mutu dan memberikan kultur islami/religius di sekolah. Kepemimpinan adalah suatu kekuatan penting dalam rangka pengelolaan madrasah, oleh sebab itu

128 Jakaria Sembiring, Sulitnya Mencari Pemimpin Yang Jujur dan Bersih, Diunduh pada tanggal 15 September 2020, Pukul 12.00 WIB, Dari https://analisadaily.com/berita/arsip/2015 /2/26/111511/sulitnya-mencaripemimpin-yang-jujur-dan-bersih/

${ }_{129}$ Iqbal M. Syahid, Data KPK 2004-2019: Korupsi Terbanyak Di Pemerintah Pusat, Polisi Paling Sedikit. Diunduh Tanggal 15 September 2020, Pukul 12.32 WIB, Dari https://seputartangsel.pikiran-rakyat.com/nasional/pr-14581448/data-kpk2004-2019-korupsi-terbanyak-di-pemerintah-pusat-polisi-paling-sedikit?page $=2$ 
kemampuan memimpin secara efektif merupakan kunci keberhasilan organisasi madrasah.

Kondisi saat ini, efektifitas madrasah dalam mewujudkan prestasi madrasah masih rendah. Derjan Pendis (Kemenag) menyebutkan masalah yang dihadapi madrasah meliputi tatakelola, kualitas siswa madrasah dinilai kurang unggul dalam bidang studi umum, dan kualitas guru. ${ }^{130}$ Kepemimpinan yang efektif selalu dikaitkan dengan keberhasilan sebuah madrasah. Ada korelasi yang signifikan antara peningkatan kerja organisasi madrasah dengan efektifitas seorang pemimpin. Dalam menjalankan tugasnya sebagai pemimpin akan mencerminkan sikap dan pandangan pemimpin terhadap orang yang dipimpinnya. Hal tersebut dapat mencerminkan gaya kepmimpinan seorang pemimpin. Gaya tersebut mampu menentukan terhadap respon orang yang dipimpinnya.

Sehingga, dari uraian di atas sangatlah penting dan dibutuhkan menjadi seorang pemimpin yang efektif dan berpengaruh pada bawahannya untuk mensukseskan madrasah yang dipimpinnya. Teramat penting peran menjamin mutu madrasah, penulis menguraikan sebuah kajian bagaimana menjadi seorang pemimpin yang efektif dan berpengaruh di madrasah.

\section{Metode Penelitian}

Penelitian menggunakan pendektan kualitatif, jenis penelitian ini adalah studi pustaka (library research). Penelitian ini menggunakan buku-buku, artikel kepemimpinan untuk mencari fakta-fakta ilmiah. Data-data yang diperoleh dari buku-buku, artikel dan berita kemudian dianalisis dengan metode deskriptif analisis. Menggambarkan fakta-fakta ilmiah kepemimpian dalam bentuk deskripsi, kemudian dianalisis secara komprehensif, dengan memberikan pemahaman dan penjelasan pada faktafakta temuan.

\section{Hasil Penelitian dan Pembahasan}

Menjadi seorang pemimpin yang efektif dan bisa mempengaruhi yang dipimpinnya memang bukan persoalan mudah. Menjadi seorang pemimpin sukses adalah dambaan semua pemimpin. Kepala sekolah yang efektif dan berpengaruh mampu meningkatkan mutu madrasah yang dipimpinnya. Hal tersebut merupakan salah satu tanda kesusesan seorang pemimpin. Untuk menggambarkan kepemimpinan tersebut, dapat dikenali ciri-cirinya sebagai berikut.

1. Pemimpin dan Meneger

\footnotetext{
130 Maulana Kautsar, 4 Masalah Pendidikan yang Dialami Madrasah, Diunduh pada tanggal 09 September 2020, Pukul 21.40 WIB, Dari https:// www.dream.co.id/news/dirjen-pendis-sebut-ada-4-masalah-besar-dipendidikan-madrasah-191202z.html.
} 
Kepemimpinan menurut Istiningsih adalah setiap perbuatan yang dilakukan individu atau kelompok untuk mengkoordinasi dan memberi arah kepada indvidu atau keompok yang tergabung di dalam wadah tertentu untuk mencapai tujuan yang telah ditetapkan sebelumnya. Kepemimpinan adalah suatu kegiatan memengaruhi orang lain agar orang tersebut mau bekerja sama (mengolaborasi dan mengelaborasi potensinya) untuk mencapai tujuan yang ditetapkan. Kepemimpinan juga sering dikenal sebagai kemampuan untuk memperoleh consesnsus angota organisasi untuk melakukan tugas menejemen agar tujuan organisasi tercapai. ${ }^{131}$ Melihat pengertian yang dikemukakan oleh Istiningsih menandakan Peran utama seorang pemimpin adalah mempengaruhi orang lain untuk secara sukarela mau bekerjasama mencapai sasaran yang telah ditetapkan. Kepemimpinan dan menejemen mempunya cara kerja yang berbeda, menejemen bekerja dengan tujuan agar semua berjalan dengan lancar demi tercapainya tujuan yang telah ditentukan.

Kepemimpinan erat kaitannya dengan pemimpin, begitu pula menegemen juga erat kaitannya dengan meneger. Pemimpin ialah orang yang menciptakan visi dan menginspirasi orang lain untuk mencapai visi tersebut dan memperluas mereka diluar kapabilitas normalnya. Sedangkan meneger merencanakan aktivitas, mengorganisir strukturnya yang sesuai, dan mengontrol sumber daya. ${ }^{132}$ Meneger menghargai stabilitas, keteraturan dan efisiensi, sementara pemimpin menghargai fleksibelitas, inovasi, dan adaptasi. Meneger sangat memperhatikan bagaimana suatu diselesaikan dan mereka membuatnya untuk orangorang agar melakukannya dengan baik. Pemimpin memperhatikan apa arti bebagai hal bagi orang dan berusaha agar orang menyepakati hal-hal terpenting yang harus dilakukan. ${ }^{133}$

Perbedaan antara pemimpin dan meneger dapat dibandingkan pada tabel berikut:

Tabel 1

Kepribadian leader dan meneger

\begin{tabular}{|l|l|}
\hline \multicolumn{1}{|c|}{ Pemimpin / Leader } & \multicolumn{1}{c|}{ Meneger } \\
\hline Berinovasi & Mengelola \\
Mengembangkan & Memelihara \\
Menginspirasi & Kontrol \\
\hline
\end{tabular}

131 Istiningsih, Kepemimpinan Pedidikan dan Pengembangan SDM (Yogyakarta: Program Magister FITK UIN Sunan Kaljaga, 2017), hal. 10.

132 Wibowo, Kepemimpinan: Pemahaman Dasar Pandangan Konvensional, Gagasan Kontemporer (Jakarta: PT Raja Grafindo Persada, 2016), hal. 16.

133 Gary Yukl, Kepemimpinan dalam Organisasi edisi kelima terjemahan dari Leaddership in Organization (Indonesia: Indeks, 2010), hal. 7. 


\begin{tabular}{|l|l|}
\hline $\begin{array}{l}\text { Bertanya tentang apa dan } \\
\text { mengapa }\end{array}$ & $\begin{array}{l}\text { Bertanya tentang bagaimana } \\
\text { dan kapan meniru }\end{array}$ \\
$\begin{array}{l}\text { Pandangan jangka panjang } \\
\text { Menentang ststus quo }\end{array}$ & $\begin{array}{l}\text { Pandangan jangka pende } \\
\text { Memelihara status quo }\end{array}$ \\
\hline
\end{tabular}

Berdasarkan tabel di atas, kita menyadari bahwa meneger dan pemimpin adalah orang yang berbeda, proses kerja yang dilakukan seorang pemimpin dan meneger sangat bertentangan. Namun, organisasi perlu kepemimpinan dan menejemen yang kuat untuk mendapatkan efektivitas secara optimal, karena Menejemen yang kuat saja hanya kan menciptakan birokrasi tanpa tujuan. Sedangkan kepemimpinan yang kuat saja dapat menciptakan perubahan yang tidak praktis dan efisien. Sehingga seorang pemimpin dan seorang menejer yang kuat sangat dibutuhkan demi keefektifan dan keoptimalan organisasi.

2. Menegemen Berbasis Madrasah (MBM)

Terdapat beberapa konsep dalam mendefinisikan Manajemen Berbasis Madrasah, yaitu: (1) Manajemen Berbasis Madrasah (MBM) adalah strategi untuk mewujudkan madarah yang efektif dan produktif; (2) Manajemen Berbasis Madrasah (MBM) merupakan paradigma baru manajemen pendidikan, yang memberikan otonomi luas pada madrasah, dan pelibatan masyarakat dalam kerangka kebijakan pendidikan nasional; (3) Manajemen Berbasis Madrasah (MBM) adalah ide tentang pengambilan keputusan pendidikan yang diletakan pada posisi yang paling dekat dengan pembelajaran. ${ }^{134}$

MBM merupakan suatu konsep yang menawarakan otonomi secara luas pada sekolah untuk menentukan kebijakan sekolah dalam rangka meningkatkan mutu, efisiensi, dan pemerataan pendidikan agar dapat mengakomodasi keinginan masyarakat setempat serta menjalin kerjasama yang erat antar sekolah, masyarakat, dan pemerintah.

Peningkatan efisien dapat diperoleh melalui keleluasan mengelola sumber daya yang ada, pertisipasi masyarakat, dan penyederhanaan birokrasi. Peningkatan mutu diperoleh melalui partisipasi orang tua, kelenturan pengelolaan madrasah, peningkatan profesionalisme guru serta hal lain yang dapat menumbuhkembangkan suasana kondusif. Sedangkan pemerataan pendidikan tampak pada tumbuhnya partisipasi masyarakat yang mampu dan peduli, sementara yang kurang mampu akan menjadi tanggung jawab pemerintah. ${ }^{135}$

${ }^{134}$ Ari Hasan Ansori, Pentingnya Manajemen Berbasis Sekolah/Madrasah Dalam Kepemimpinan Sekolah/Madrasah Efektif, Jurnal TARBAWI Volume 2. No. 01, JanuariJuni 2016, hal. 27.

135 E. Mulyasa, Menejemen Berbasis Sekolah (Bandung: Remaja Rosdakarya, 2004), hal. 13. 
Adanya keleluasan otonomi yang diberikan pemerintah kepada kepala sekolah, ini memberikan peluang kepada madrasah, guru dan peserta didik untuk melakukan inovasi dan improvisasi di madrasah berkaitan dengan masalah kurikulum, pembelajaran, menejerial. Pelibatan Madrasah dengan masyarakat mendorong sekolah untuk lebih bersikap demokratis dan terbuka. Sehingga Menejemen Berbasis Madrasah (MBM) merupakan suatu konsep menjemen yang sangat efektif dan dapat menentukan keberhasilan sekolah.

3. Gaya kepemimpinan bos

Kadangkala, ada orang yang mengartikan Boss dengan pemimpin adalah sama, dimana orang menganggap yang memiliki jabatan lebih tinggi disuatu perusahaan instansi itu adalah bos. Sebenarnya hal ini tidaklah benar, sebenarnya antara bos dan pemimpin adalah dua sosok yang berbeda.

Bos adalah orang yang memerintahkan anak buahnya bekerja keras tanpa mengarahkan atau mengerjakan serta membimbing bawahannya jika terjadi kesalahan. Yang ada dalam pikiran bos, jika bawahannya bersalah harus dimarahi bahakan di maki-maki, tanpa diberi pengarahan, bagaimana cara melaksanakan apa yang diinginkannya. Seorang bos merasa bangga dan senang jika bawahannya takut terhadap dia, bahkan seorang bos akan merasa menjadi seorang pemimpin dengan cara seperti itu, namun sebenarnya hal ini adalah salah. ${ }^{136}$

Ekspresi wajah antara bos dan pemimpin juga berbeda. Seorang bos sering memasang wajah masam, kurang bersahabat, wajah yang seperti terlihat merendahkan bawahannya, beda halnya dengan seorang pemimpin, dai selalu memasang wajah ramah, murah senyum, terkesan menghargai bawahannya, dan lebih bersahabat.

Lalu tentang keuntungan, bukan keuntungan arti uang, sebagai contoh, nama baik organisasi, seorang bos akan memakan itu sendiri jika ada yang memuji organisasinya, dia akan mengatakan bahwa itu semua karena dirinya, kerja kerasnya, tetapi seorang pemimpin akan mengatakan bahwa itu hasil kerjasama, dia akan membagi nama baik itu kepada bawahnnya.

Tentang pola pikir dalam mengerjakan tugas yang diberikan, seorang bos akan mengatur pekerjaan itu, maksudnya jika bos ingin tugas yang ia berikan diselesaikan seperti A maka bawahan harus ikut, harus seperti apa yang bos inginkan. Seorang pemimpin akan membiarkan rekannya bekerja sesuai pola pikir mereka, cara pandang

136 Parlin Nainggolan, Perbedaan Seorang Bos dengan Pemimpin, Diunduh pada tanggal 09 September 2020, Pukul 21.55 WIB, Dari https://www.kompasiana.com/parlin_nainggolan /550acc7da33311cb102e3a1e $\angle$ perbedaan-seorang-bos-dengan-pemimpin. 
mereka atas tugas tersebut. Sehingga akan memeberi warna baru, karena bisa jadi dengan itu berdampak baik untuk organisasinya.

Selanjutnya, seorang bos memiliki ruang tersendiri untuk dirinya. Dia menjaga jarak dengan bawahannya, ada space diantara mereka. Seorang bos "focus on process" maksudnya fokus pada perkerjaan yang bawahannya kerjakan, fokus pada cara pengerjaan dan hasil kerjanya, sedangkan seorang pemimpin "focus in people" dia berorientasi pada bawahnnya dan lebih memanusiakan bawahannya. ${ }^{137}$

Dari uraian diatas dapat dipahami bahwa tipe kepemimpinan bos adalah tipe kepemimpinan yang tidak efektif dan tidak berhasil dalam mensukseskan organisasinya serta tidak mampu dalam memberikan kesejahteraan untuk bawahannya. Maka, tipe kepemimpinan seperti ini harus sangat dihindari oleh seorang pemimpin.

4. Kepemimpinan Kepala Sekolah yang Efektif dan Berpengaruh

Efektif ialah cara mencapai suatu tujuan dengan pemilihan cara yang benar dari beberapa alternatif, kemudian mengimplimentasikan pekerjaan dengan tepat dengan waktu yang cepat. Ukuran yang paling banyak digunakan untuk mengukur efektifitas pemimpin adalah seberapa jauh unit organisasi pemimpin tersebut berhasil menunaikan tugas pencapaian sasarannya. Efektifitas pemimin kadang-kadang diukur berdasarkan konstribusi pemimpin pada kualitas proses kelompok yang dirasakan oleh para pengikut dan pengamat dari luar. ${ }^{138}$

Kepala sekolah secara efektif mampu menunjukan kemampuan menggambarkan potensi-potensi sekolah, guru, dan siswa untuk mencapai potensi maksimal. Kepala sekolah efektif mampu meningkatkan potensi sekolah dengan menunjukan kemampuannya dalam mengelola sekolah, guru, dan siswa sebagai komponen utama untuk mencapai tujuan sekolah. 139

Kriteria kepala sekolah yang efektif ialah mampu menciptakan atmosfir kondusif bagi murid-murid untuk belajar dan para guru untuk terlibat. Iklim skolah yang efktif dalam segala bidang merupakan citacita yang diharapkan semua sekolah dan guru atau karyawan. Namun kembali lagi ditegaskan bahwa semua hal itu tergantung pada siapa pemimpinnya. Kepala sekolah yang efektif dalam menjalankan tugas kepemimpinannya dapat dilihat ciri-cirinya sebagai berikut:

Kriteria kepemimpinan kepala sekolah yang efektif menurut Mulyasa dalam Mulyadi sebagai berikut:

137 Nadia Nur, Pola kepemimpinan Bos dan Pemimpin, Diunduh pada tanggal 09 September 2020, Pukul 22.08 WIB, Dari https://www.kompasiana.com/ nadianur/5652c1ecd39273a0147b687c/pola-kepemimpinan-bos-dan-pemimpin.

138 Gary Yukl, Kepemimpinan dalam Organisasi,... hal. 10.

139 Daryanto, Kepala Sekolah sebagai Pemimpin Pembelajaran (Yogyakarta: Gava Media, 2011), hal. 99. 
1. Mampu memperdayakan guru-guru untuk melakasanakan proses pembelajaran dengan baik, lancar dan produktif.

2. Dapat menjalankan tugas dan pekerjaan sesuai dengan waktu yang telah ditetapkan

3. Mampu menjalin hubungan yang harmonis dengan masyarakat, sehingga dapat melibatkan mereka secara aktif dalam rangka mewujudkan tujuan sekolah dan pendidikan.

4. Berhasil menerapkan prinsip kepemimpinan yang sesuai dengan tingkat kedewasaan guru dan pegawai di sekolah.

5. Mampu bekerja dengan tim menegemen sekolah.

6. Berhasil mewujudkan tujuan sekolah secara produktif sesuai dengan ketentuan yang telah berlaku. ${ }^{140}$

Menurut hemat penulis, dilihat dari kritria di atas jadi seorang pemimpin yang efektif adalah pmimpin yang mampu menjalankan tugas dan perannya sebagai kepala madrasah dan mampu berintraksi dan berkolaborasi dengan baik dengan para staf dan guru hingga lapisan masyarakat untuk mewujudkan tujuan sekolah secara produktif, cepat, dan tepat.

Menurut ivancevich, Konopaske, dan Matteson dalam Wibowo mengungkapkan bahwa Efektivitas kepemimpinan antara lain juga dapat ditunjukan oleh sifat pemimpin dalam dimensi inntelligence, personality, dan abilities. Sifat-sifat tersebut dapat dirinci sebagai berikut: ${ }^{141}$

Tabel 2

Dimensi Sifat Pemimpin Efektif

\begin{tabular}{|l|l|l|}
\hline Intelliegence & Personality & Abilities \\
\hline -Pertimbangan & -Kemampuan & -Kemampuan \\
-Ketegasan & adaotasi & meminta kerja sama \\
-Pengetahuan & -Kewaspadaan & -Kerjasama \\
-Kelancaran & -Kreativitas & -Popularitas dan \\
berpidato & -Percaya diri & prestise \\
& -Keseimbangan & -Keteranpilan \\
& emosional dan & interpersonal \\
& kontrol & -Partisipasi sosial \\
& Kebebasan & -Kebijaksanaan \\
& & diplomasi \\
\hline
\end{tabular}

Berdasarkan tabel di atas menunjukan bahwa keefektifan seorang pemimpin dapat diukur melalui sifat yang ditunjukan pemimpin pada

140 Mulyadi, Kepemimpinan Kepala Sekolah dalam Mengmbangkan Budaya Mutu (Malang: UIN Maliki Prss, 2010), hal. 69-70.

141 Wibowo, Kepemimpinan: Pemahaman Dasar......., hal. 23. 
setiap dimensinya. Dengan ini dapat dipahami bahwa terdapat kesulitan dalam mengukur efektivitas pemimpin, dan tidak jelas alat ukur relevan yang digunakan untuk menunjukan efektivitas pemimpin. Namun, menurut penulis, inti mengukur keefektifan pemimpin adalah Trust) kepercayaan). Kepercayaan itulah modal awal kesuksesan seorang pemimpin di masa depan. Hal ini sejalan dengan konsep yang digambarkan oleh HRD Indonesia.

Dalam konsep yang digambarkan oleh HRD Indonesia mengungkapkan bahwa trust (kepercayaan) adalah inti dan pusat kepemimpinan yang efektif. Seorang pemimpin akan menjalankan kepemimpinanya jika ia mendapat kepercayaan dari lingkungan organisasinya, baik lingkungan internal maupun ekseternal. Untuk mendapatkan kepercayaan itu, maka seorang pemimpin harus mewujudkan secara seimbang tiga hal penting yaitu; Integritas, kepedulian dan hasil. ${ }^{142}$

Pada pembahasan sebelumnya telah dikatakan bahwa peran seorang pemimpin adalah mempengaruhi orang lain atau bahwahannya. Kelman dalam Sashkin mengungkapkan bahwa terdapat tiga strategi bagaimana orang dipengaruhi, sebagai berikut: ${ }^{143}$

a. Memperoleh Imbalan atau Menghindari Hukuman

Stategi pertama ini digunakan pemimpin untuk mempengaruhi orang lain bilamana seseorang mau bekerja melakukan sesuatu dengan menawarkan imbalan misalnya uang kepada orang itu. Hukuman adalah hal sebaliknya dari imbalan. Artinya orang tersebut tidak dibayar dan tidak diberhentikan. Hal seperti ini merupakan model keberpengaruhan bagi kepemimpinan transaksional.

b. Internalisasi Nilai-Nilai Bersama

Nilai-nilai dan keyakinan ini merupakan pandangan yang dipegang kuat dan berfungsi sebagai penuntun untuk mengerjakan yang benar. ${ }^{144}$ Contohnya saya memiliki rumah dan jalan umum. Didepan rumah saya kotor, kemudia saya menyapu jalan tersebut bukan karena penghuni rumah lain atau RT setempat membayar saya, melainkan saya menggunakan jalan tersebut sama seperti orang lain. yang digaris bawahi di sini adalah pandangan dan nilai bersama bahwa jalan yang bersih akan menjadi aman dan nyaman untuk digunakan. Artinya semua pihak bisa saling berbagi rasa hormat dan kepedulian untuk memelihara sifat yang menguntungkan mereka.

142 Jamal Lulail Yunus, Leadership Model: Konsep Dasar, Dimensi Kerja dan Gaya Kepemimpinan (Malang: UIN Maliki Press, 2009), hal. 108.

143 Marshall Sashkin dan Molly G Shahkin, Terjemahan, Prinsip-Prinsip Kepemimpinan (Indonesia: Erlangga, 2011), hal. 70.

144 Ibid., hal. 71. 
Model seperti ini adalah yang digunakan oleh pemimpin transformasional.

c. Pengidentifikasian dengan Pemimpin

Kunci keberpengaruhan yang ketiga merupakan kunci untuk memahami kepemimpinan karismatik. Pemimpin seperti ini menyakinkan para pengikutnya bahwa dengan mengerjakan apa yang diperintahkannya, yaitu bertindak seperti apa yang diperintahkan pemimpinnya, pengikut akan menjadi seperti pemimpin. ${ }^{145}$

Terdapat beberapa studi tentang keefektifan dan keberhasilan sekolah sukses. Menurut Cheng dalam Raihani menunjukan bahwa sekolah dikatakan efektif jika mempunyai kapasitas untuk memaksimalkan pencapaian tujuan-tujuan dan fungsi sekolah. Edmonds dalam raihani menyatakan bahwa dalam karakteristik sekolah yang efektif dinilai dari perubahan-perubahan dalam karakteristik organisasional sekolahnya yang mencakup fokus pada pendidikan dasar, kepemimpinan instruksional, ekspektasi-ekspektasi akademik yang tinggi, ketertiban, dan suasana sekolah yang positif. Menurut razik dan swanson kepemimpinan merupakan hal yang pokok untuk mengembangkan dan mengefektifkan sekolah dapat berjalan efektif jika kepala sekolahnya mampu menciptakan atmosfir ketertiban, kedisiplinan dan bertujuan. Sebuah suasana yang penuh harapan bagi para staf dan siswa, hubungan kerjasama yang baik antar staf, komitmen antar siswa dan staf untuk mencapai tujuan, dan pengembangan staf yang memadai. ${ }^{146}$

5. Kepemimpinan Transformasional di Madrasah

Kepemimpinan transformasional adalah model kepemimpnaan yang berangkat dari keinginan kuat untuk mentransformasi organisasi menuju perubahan dan perbaikan. Burn menjelaskan bahwa kepemimpinan transformasional adalah sebuah prosess dimana pemimpin dan para bawahannya berusaha untuk mencapai tingkat moralitas dan motivasi yang lebih tinggi. ${ }^{147}$ Ini berarti pemimpin transformasional mencoba untuk membangun kesadaran para bawahannya dengan menyerukan cita-cita yang besar dan moralitas yang tinggi seperti kejayaan, kebersamaan dan kemanusiaan. Pemimpin transformasional melakukan stimulus, motivasi, menginspirasi, dan memberikan perhatian individu yang dipimpin.

Menurut bass dalam Yukl bahwa pemimpin mengubah dan memotivasi para pengikut dengan membuat mereka lebih menyadari

145 Ibid., hal. 71-72.

146 Raihani, Kepemimpinan Sekolah Transformatif (Yogyakarta: Lkis, 2010), hal. 8.

147 Mohammad Karim, Pemimpin Transformasional di Lembaga Pendidikan Islam (Malang: UIN Maliki Press, 2010), hal. 4. 
pentingnya tugas, membujuk mereka untuk mementingkan kepentingan tim atau oragnisasi mereka dibandingkan dengan kepentingan pribadi, dan mengaktifkan kebutuhan mereka yang lebih tinggi. ${ }^{148}$ Komitmen dari team work madrasah juga menjadi faktor penentu kuatnya madrasah. Komitmen ini meliputi keyakinan dan penerimaan kuat mengenai tujuan dan nikai-nilai organisasi, kesediaan bekerja menjadi bagian organisasi, dan bersungguh-sungguh tetap menjadi anggota organisasi. ${ }^{149}$ Fokus kepemimpinan transformasional adalah komitmen dan kapasitas anggota organisasi. Komitemen dan kapasitas yang semakin bertambah dianggap dapat menghasilkan usaha dan produktivitas yang lebih besar dan akan menjadi outcome yang diharapkan oleh sebuah organisasi. ${ }^{150}$

Kepemimpinan trasnformasional ini berbeda dengan model kepemimpinan yang lain. Dalam kepemimpinan transformasional seorang pemimpin fokus pada transformasi nilai-nilai dalam diri anggota organisasi agar berdampak terhadap transformasi organisasi dengan terwujudnya visi dan misi. Beberapa alasan mendasar mengapa kepemimpinan model tranformasi ini dianggap model kepemimpinan yang efektif karena dalam sebuah organisasi pemimpin yang membawa perubahan dan perbaikan (transformastion to improvemen) merupakan hal yang terpenting dari tujuan manusia dan organisasi.

Kelebihan yang ditawarkan dari model kepemimpinan transformasional terletak pada cara pemimpin dalam mengkomunikasikan perubahan terhadap semua pihak, pola hubungannya dengan pemimpin. Model kepemimpinan ini didasarkan pada keinginan besar menarik pribadi-pribadi yang dipimpin kepada kemerdekaan dan kebebasan dengan memenangkan hati, pikiran dan prilaku mereka tanpa dengan merekayasa, penguasaan atau penaklukan atas diri mereka. ${ }^{151}$

Menurut Bass Dan Avolio dalam Junaidah, Dimensi-dimensi kepemimpinan Transformasional yaitu:

1. Idealized Influenced, perilaku yang menghasilkan rasa hormat (respect) dan rasa percaya dari orang- orang yang dipimpinnya.

2. Inspirational Motivation, senantiasa menyediakan tantangan dan makna atas pekerjaan orang-orang yang dipimpinnya.

3. Intellectual Simulation, senantiasa menggali ide-ide baru dan solusi yang kreatif dari orang-orang yang dipimpinnya.

148 Gary Yukl, Kepemimpinan dalam Organisasi edisi kelima terjemahan......., hal. 305.

149 Nurtanio Agus P, Mengembangkan Prilaku Asertif Kepala Sekolah, dalam Jurnal Internasional Menejemen Pendidikan, Vol.2, No.4, 2010, hal. 53.

150 Raihani, Kepemimpinan Sekolah .........., hal. 20.

151 Mohammad Karim, Pemimpin Transformasional.........., hal. 9. 
4. Individualized consideration, memberikan perhatian khusus kepada kebutuhan prestasi dan kebutuhan orang yang dipimpinnya. ${ }^{152}$

Kepemimpinan transformasional memiliki lima tuntutan kepemimpinan yaitu; tuntutan teknis, sumber daya manusia, edukaisonal, simbolik dan kultural. Tuntutan teknis kepemimpinan mencakup teknik-teknik menejemen yang sehat sebagai syarat setiap organisasi; tuntutan sumber daya manusia mencakup pemanfaatan potensi-potensi sosial dan interpersonal dari sekolah yaitu sumber daya manusianya; tuntutan edukasional menunjukan pengetahuan yang baik tentang pendidikan dan persekolahan; tuntutan simbolik memberi tekanan dan contoh pada tujuan dan sikap; tuntutan kultural mendefinisikan, menguatkan, dan mengartikulasikan nilai-nilai hidup, kepercayaan, dan kultur yang memberikan identitas pada sekolah dari waktu ke waktu. ${ }^{153}$

6. Profil Pemimpin Madrasah yang Efektif

Efektivitas merupakan unsur pokok untuk mencapai tujuan atau sasaran yang telah ditentukan di dalam setiap organsiasi, kegiatan maupun program. Disebut efektif apabila tercapai tujuan atau sasaran seperti yang telah ditentukan. Hal ini sesuai dengan pendapat Andang yang menyatakan bahwa efektifitas adalah pengkuran dalam arti memaksimalkan segenap potensi dan peluang yang ada untuk menghasilakan sesuatu yang optimal. ${ }^{154}$

Madrasah efektif adalah madrasah mampu menetapkan keberhasilan pada input, proses, output, dan outcome madrasah, yang ditandi dengan berkualitasnya komponen-komponen sistem madrasah tersebut. ${ }^{155}$ Kualifikasi menjadi kepala madrasah terdapat dalam UU No 37 tahun 2007 tentang standar kepala Sekolah/madrasah. Terdapat kualifikasi umum dan kualifikasi khusus sesuai tingkatan sekolah/ madrasah. Kualifikasi tersebut merupakan sayarat untuk bisa menjadi kepala sekolah di madrasah. ${ }^{156}$ Kualifikasi tanpa kualitas penulis rasa nihil nilainya. Menjadi pemimpin yang berkualitas dan efektif di madarasah dapat menuaikan keberhasilan bagi madrasah/sekolah.

152 Junaidah, Kepemimpinan Transformasional dalam Pendidikan, dalam Jurnal IAIN Raden Intan lampung, hal. 116.

153 Raihani, Kepemimpinan Sekolah , hal. 34 .

${ }^{154}$ Abdul Shomad Dan Agus Sunarko, Kepemimpinan Efektif Kepala Madrasah Pada Badan Pelaksana Pendidikan (Bpp) Ma'arif Nu Raudlatul Mu'allimin Wedung Demak (Studi Kasus Di Mts Nu Dan Ma Nu Raudlatul Mu'allimin Wedung Demak), Jurnal Quality Vol. 4, No. 2, 2016, hal. 294-295.

155 Awang Setiawan, Konstribusi Kepemimpinan Transformasional Kepala Sekolah Dan Iklim Sekolah Terhadap Efektivitas Sekolah, Jurnal Administrasi Pendidikan Vol. XXIII, No. 01, April 2016, hal.132.

156 Lihat Lampiran Permendiknas No 37 Tahun 2007. 
Profil kepemimpinan yang efektif dalam lembaga pendidikan islam di UIN Malang yunus menyebutnya sebagai ulul albab leadership style, dengan menggunakan pendekatan kasih sayang, keteladanan, apresiasi, dan persaudaraan dan kemanusiaan. ${ }^{157}$ Berikut uraian lengkapnya.

Pertama, pendekatan kasih sayang. Cinta dan kasih sayang adalah pondasi dari ketenangan dan kebahagiaan. Cinta dan kasih sayang merupakan kebutuhan ruhani yang paling dapat dinikmati. Suatu aktivitas apaun itu jika dilandasi dengan perasaan cinta, betapapun beratnya akan terasa ringan. Cinta laksana dopping yang mampu meningkatkan kualitas pekerjaan seseorang berlipat-lipat. Cinta itulah yang membuat pemimpin merasa senang, puas dan bertanggung jawab atas amanah kepemimpinannya. Selaian rasa cinta dan kasih sayang, kelemahlembutan seorang pemimpin mendorong hubungan antara pemimpin dan yang dipimpin penuh dengan suasana kasih sayang, saling memahami, saling percaya, terbuka yang akhirnya menimbulkan semangat berkreatifitas dan berinovasi. ${ }^{158}$

Kedua, pendekatan keteladanan. Keteladanan merupakan salah satu gaya kepemimpinan yang diterapkan oleh seorang pemimpin untuk melakukan gerakan yang bersifat kultural. Dalam mengembangkan budaya amal shalih harus dilakukan dengan ibda' bi nafsika (dimulai dari diri sendiri). Prilaku tersebut sangat berhasil dalam mengembangkan kultur religius di UIN malang karena dalam jiwa manusia memiliki kecendrungan untuk meniru, merupakan suatu fitrah dan naluri manusiawi. 159

Ketiga, pendekatan apresiasi. Apresiasi seorang pemimpin sangat dibutuhkan untuk penyeimbang antra kontrol dan motivasi yang harus tetap tumbuh pada setiap elemen organisasi. Antara apresiasi positif dan negatif porsinya harus seimbang sesuai dengan porsinya masing-masing. Bentuk apresiasi itu bermacam-macam seperti memberikan penghargaan, sanjungan atas kemampuan dan kapabilitasnya yang positif serta memunculkannya, memberikan pujian pada jasa baik meskipun sedikit, jangan ragu memberikan hadiah bagi orang yang berkontribusi kepada pengembangan lembaga. Rektor UIN Malang sering memberikan beasiswa kepada mahasiswanya yang berperstasi dengan membebaskan biaya lanjut S2. ${ }^{160}$

Keempat, pendekatan persaudaraan dan kemanusiaan. Pendekatan ini dalam ajaran islam dikenal dengan ukhuwah. Nilai

157 Jamal Yulail Yunu, Leadership Model: Konsep Dasar, Dimensi Kerja, dan Konsep Kepemimpinan (Malang: Uin Maliki Press, 2009), hal. 146.

158 Ibid., hal. 146-156.

159 Ibid., hal. 157-160.

160 Ibid., hal. 161-163. 
ukhuwah ini yang akan mengikat seseorang satu dengan yang lainnya. Untuk mendapatkan jalinan yang kukuh antra semua komponen warga kampus demi persatuan dan kesatuan, maka harus dikembangkan ta'aruf (saling mengenal) satu sama lain. ta'aruf akan melahirkan tafahum (saling memahami), tafahum akan melahirkan tadhamun yakni saling menghargai. Tadhamun akan melahirkan tarahum (saling meyayangi) yang pada akhirnya lahirah suasana ta'awun (saling menolong). Rektor UIN Malang melakukan proses ta'aruf sampai ke ta'awun dengan cara jalan sehat, shalat berjamaah, khatmul qur'an, olahraga, makan bersama, pengajian rutin. ${ }^{161}$

Dapat ditarik kesimpulan, dari profil pemimpin diatas dapat dikatakan sebagai pemimpin efektif dan mampu menciptakan madrasah yang sukses. Tentunya, setiap pemimpin sukses memiliki kriteria yang berbeda, cara dan stategi yang berbeda. Perbedaan tersebut disesuaikan dengan kondisi sosial-lingkungan madrasah/ sekolah yang dipimpinnya.

\section{Kesimpulan}

Pemimpin dan menejer adalah dua orang berbeda. Pemimpin dan meneger yang kuat dibutuhkan dalam organiasasi untuk keberhasilan sebuah organisasi. Ukuran keefektifan dan keberpengaruhan pemipin di setiap madrasah berbeda-beda. Membangun trus (kepercayaan) warga sekolah dan semua lapisan masyarakt melalui gaya kepemimpinanya adalah kunci untuk membuka jalan keberhasilan seorang pemimpin. Ulil albab adalah sebutan untuk profil pemimpin yang efektif dan berpengaruh dalam kelembagaan islam atau madrasah.

\section{Daftar Pustaka}

Ansori, Ari Hasan. Pentingnya Manajemen Berbasis Sekolah/Madrasah Dalam Kepemimpinan Sekolah/Madrasah Efektif. Jurnal TARBAWI Volume 2. No. 01, Januari-Juni 2016, hal. 27.

Daryanto. Kepala Sekolah sebagai Pemimpin Pembelajaran. Yogyakarta: Gava Media, 2011.

Istiningsih. Kepemimpinan Pedidikan dan Pengembangan SDM. Yogyakarta: Program Magister FITK UIN Sunan Kaljaga. 2017.

Junaidah. Kepemimpinan Transformasional dalam Pendidikan. dalam Jurnal IAIN Raden Intan lampung. hal. 116.

Karim, Mohammad. Pemimpin Transformasional di Lembaga Pendidikan Islam. Malang: UIN Maliki Press. 2010.

Kautsar, Maulana. 4 Masalah Pendidikan yang Dialami Madrasah, Diunduh pada tanggal 09 September 2020. Pukul 21.40 WIB. Dari

161 Ibid., hal. 164-168. 
https://www.dream.co.id/news/dirjen-pendis-sebut-ada-4-masalahbesar-di-pendidikan-madrasah-191202z.html

Lampiran Permendiknas No 37 Tahun 2007.

Mulyasa, E. Menejemen Berbasis Sekolah. Bandung: Remaja Rosdakarya, 2004.

Mulyadi. Kepemimpinan Kepala Sekolah dalam Mengmbangkan Budaya Mutu.

Malang: UIN Maliki Prss. 2010.

Nainggolan, Parlin. Perbedaan Seorang Bos dengan Pemimpin. Diunduh pada tanggal 09 September 2020. Pukul 21.55 WIB. Dari https://www.kompasiana.com/

parlin_nainggolan/550acc7da33311cb102e3a1e/perbedaan-seorangbos-dengan-pemimpin.

Nur, Nadia. Pola kepemimpinan Bos dan Pemimpin. Diunduh pada tanggal 09 September 2020. Pukul 22.08 WIB. Dari https://www. kompasiana.com/nadianur /5652c1ecd39273a0147b6 87 c/polakepemimpinan-bos-dan-pemimpin.

P, Nurtanio Agus. Mengembangkan Prilaku Asertif Kepala Sekolah, dalam Jurnal Internasional Menejemen Pendidikan, Vol.2, No.4, 2010, hal. 53.

Raihani, Kepemimpinan Sekolah Transformatif . Yogyakarta: Lkis. 2010.

Sashkin, Marshall dan Shahkin, Molly G. Terjemahan, Prinsip-Prinsip Kepemimpinan. Indonesia: Erlangga. 2011.

Setiawan, Awang. Konstribusi Kepemimpinan Transformasional Kepala Sekolah Dan Iklim Sekolah Terhadap Efektivitas Sekolah, Jurnal Administrasi Pendidikan Vol. XXIII, No. 01, April 2016, hal.132.

Sembiring, Jakaria. Sulitnya Mencari Pemimpin Yang Jujur dan Bersih. Diunduh pada tanggal 15 September 2020. Pukul 12.00 WIB. Dari https://analisadaily.com/berita /arsip/2015/2/26/111511/sulitnyamencari-pemimpin-yang-jujur-dan bersih/

Shomad, Abdul Dan Sunarko, Agus. Kepemimpinan Efektif Kepala Madrasah Pada Badan Pelaksana Pendidikan (Bpp) Ma'arif Nu Raudlatul Mu'allimin Wedung Demak (Studi Kasus Di Mts Nu Dan Ma Nu Raudlatul Mu'allimin Wedung Demak). Jurnal Quality Vol. 4, No. 2. 2016. hal. 294-295.

Syahid, Iqbal M. Data KPK 2004-2019: Korupsi Terbanyak Di Pemerintah Pusat, Polisi Paling Sedikit. Diunduh Tanggal 15 September 2020. Pukul $12.32 \quad$ WIB. Dari https://seputartangsel.pikiranrakyat.com/nasional/pr-14581448/data -kpk-2004-2019-korupsiterbanyak-di-pemerintah-pusat-polisi-paling sedikit?page $=2$

Wibowo. Kepemimpinan: Pemahaman Dasar Pandangan Konvensional, Gagasan Kontemporer. Jakarta: PT Raja Grafindo Persada. 2016.

Yukl, Gary. Kepemimpinan dalam Organisasi edisi kelima terjemahan dari Leadership in Organization. Indonesia: Indeks. 2010.

Yunus, Jamal Lulail. Leadership Model: Konsep Dasar, Dimensi Kerja dan Gaya Kepemimpinan. Malang: UIN Maliki Press. 2009. 